Chirurgia (2021) 116: 718-724

No. 6, November-December

Copyright@ Celsius

http://dx.doi.org/10.21614/chirurgia.116.6.718

\title{
Current Management of Colon Trauma at a Level II Trauma Center - A Single Center Review of Cases from the Last Two Decades
}

\author{
Alexandru-Constantin Carâp ${ }^{1,2}$, Roxana-Ionela Crăciun², Bogdan Socea ${ }^{1,2 *}$, Ion Păun ${ }^{3}$, Cezar Moculescu ${ }^{2}$, \\ Vlad Denis Constantin ${ }^{1,2}$
}

'Surgery Department, "Carol Davila" University of Medicine and Pharmacy, Bucharest, Romania

${ }^{2}$ Surgery Department, "St Pantelimon" Emergency Clinical Hospital, Bucharest, Romania

${ }^{3}$ Surgery Department, „CF Craiova” Clinical Hospital, Craiova, Romania

*Corresponding author:

Bogdan Socea, MD

Surgery Department

"St Pantelimon" Emergency Clinical

Hospital, Bucharest, Romania

340-342 Pantelimon st, $1^{\text {st }}$ floor

E-mail: bogdan.socea@umfcd.ro

\section{Rezumat}

Managementul actual al traumatismelor colonice într-un centru de traumă de nivel II - o revizie a cazurilor din ultimii 20 de ani

Introducere: Din punct de vedere al frecvenței, colonul este al doilea viscer cavitar lezat în traumatismele abdominale penetrante după intestinul subțire. Leziunile colonice sunt relativ frecvente în perioade de război şi aceste situații au generat conceptele actuale de management. Obiectivul cercetării noastre este de a evidenția conceptele de management actual aşa cum sunt aplicate într-un centru de traumă în ultimele două decade.

Materiale şi Metodă: Am realizat un studiu retrospectiv al experienței noastre clinice. Am căutat în baza de date a instituției noastre pacienții cu cauze externe de morbiditate şi mortalitate din ianuarie 2003 - octombrie 2021. Toți bolnavii cu leziuni colonice au fost incluşi în analiză.

Rezultate: În perioada studiată am identificat 11 pacienți de sex masculin cu leziuni de colon. Opțiunile operatorii au fost sutura primară sau formarea de colostomie fără a se realiza anastomoze şi fără a se efectua proceduri „damage-control”. Mortalitatea a fost $27,2 \%$, o valoare relativ mare față de literatura contemporană. Concluzii: Principala concluzie este că există o diferență mare între tiparul lezional din timpul războiului şi cel din societăti civile cu rate mici de leziuni penetrante. Există o nevoie clară de cercetare prospectivă, multicentrică pentru aceste populații pentru a defini mai corect opțiunile de management şi pentru a schimba 
abordarea bazată pe cercetări din timpul războaielor sau din zone geografice cu rate mari de leziuni penetrante.

Cuvinte cheie: leziuni traumatice ale colonului, traumatisme colonice

\begin{abstract}
Introduction: The large bowel is the second most commonly injured hollow viscus in penetrating abdominal trauma following the small bowel. Injuries to the colon are fairly common in times of war and the lessons learned in these instances have historically guided management. The objective of our research is to highlight current management principles as they are applied in a single trauma centre during the last two decades.

Material and method:A retrospective review of our clinical experience was performed. Electronic health records from our institution were searched for injuries caused by external forces from January 2003 - October 2021. All patients that were identified with colon injuries were included in the review.

Results: We identified 11 male patients with colon injuries during the study period. Repair options used were primary suture or colostomy formation with no anastomoses and no damage control procedures. Mortality was $27.2 \%$, relatively high when compared with contemporaneous studies. Conclusions: The main take home message of our research is that the epidemiology of colon trauma is very different in a civilian environment that has a low caseload of penetrating injury compared to wartime injuries. There is a clear need of prospective multicentre data in this type of trauma cohorts to better define management options and not base our approach on wartime data or data from communities where the rate of penetrating injuries is high.
\end{abstract}

Key words: colon injury, colon trauma

\section{Introduction}

The large bowel is the second most commonly injured hollow viscus in penetrating abdominal trauma following the small bowel. Injuries to the colon are fairly common in times of war and the lessons learned in these instances have historically guided management.

The management of traumatic injuries of the colon is problematic for the following reasons: (a) colon injuries can have a delayed diagnosis like other hollow viscus injuries and the consequences of fecal peritoneal contamination can be severe, (b) their relative infrequency can lead to a lack of familiarity with injury patterns and technical repair options, (c) they rarely present as isolated injuries and most often are part of multiple, complex injuries and (d) lack of high quality evidence does not offer clear guidance for patient management or reconstructive options.

Even though wartime experience has guided the management of traumatic colonic injuries, advances in triage, resuscitation, blood banking and antibiotics have led to a significant drop in mortality from very high values (1) to approximately $1 \%$ in the current literature. Management paradigms have shifted from mandatory colostomies for all patients (either proximal to the injury for diversion or exteriorization of the injured segment) (2) to mostly primary repair. One of the most important steps in updating the management was taken by Stone and Fabian (3) in 1979 who performed the first randomized 
trial comparing primary repair with colostomies that showed the superiority of primary repair for nondestructive injuries. The study also found longer hospital stays, increased cost of care, higher infection rates and higher overall morbidity in patients managed with a colostomy. Current management controversies are centered on destructive injuries of the colon and on the injuries occurring in patients who suffer from altered physiology and require abbreviated laparotomies or "damage control" surgery. Other issues that pose management challenges are related to the location of the injury, injuries after blunt mechanisms, primary rectal repair and presacral drainage for extraperitoneal rectal injuries.

The lessons of wartime and civilian literature up until the end of the $20^{\text {th }}$ century, as summarized by Cheong and Keshava (4), are that the non-operative management of colorectal trauma leads to poor outcomes, that colostomies greatly reduce mortality, that there is a big difference between civilian and military injuries of the colon, and that stoma formation leads to high morbidity that might suggest more prominent roles for primary repair and primary anastomosis. The objective of our research is to highlight current management principles as they are applied in a single trauma centre during the last two decades. As level one data is extremely scarce on this topic our case series can show real world evidence regarding reconstruction options used for colonic traumatic injuries.

\section{Materials and Method}

A retrospective review of our clinical experience was performed. Electronic health records from our institution were searched for injuries caused by external forces from January 2003 to October 2021. All patients that were identified with colon injuries (using ICD 9 and ICD 10 diagnostic codes) were reviewed further. For all the patients identified, we inventoried demographic data, mechanism of trauma, moment of admission, admission diagnosis, timing and type of surgical procedure (if any surgical procedure was performed), injury type [American Association for the Surgery of Trauma organ injury scale for colon and rectum (5)], clinical outcome, days to discharge or death. For the patients that required a surgical procedure we recorded the timing of surgery related to the moment of admission, the location and extent of the colon injury, the presence of associated injuries, the chosen repair option, concomitant procedures for the associated injuries, relevant details pertaining to patient physiology, use of "damage control" principles during the surgical intervention. All operative notes were reviewed by all authors and any disagreements were resolved by consensus with the final decision belonging to the first author.

\section{Results}

After reviewing all patients from January 2003 to October 2021 we identified 14301 patients that had discharge diagnoses that included accidents and external causes of injury. We excluded 167 cases that we did not consider relevant to our analysis as they were not directly caused by blunt or penetrating forces - 49 foreign body injuries, 44 patients with postoperative infections, 43 with unclassified postoperative complications, 29 patients with infected amputation stumps, and 6 infected medical devices. Of the 14134 trauma patients that remained we excluded 13272 that did not have a diagnosis of a visceral abdominal injury - 5810 had a penetrating mechanism that did not cross the serosa (parietal peritoneum, pleura), 3663 patients had contusions of the abdominal or thoracic walls, 1766 patients were treated for rib fractures and and extra 28 patients had rib fractures that led to the development of a flail chest, 598 patients had isolated thoracic injuries that presented with hemothorax or pneumothorax, 321 patients had lesions codified as superficial abdominal or thoracic wall injuries, 88 patient presented with burns, 71 with frostbite injuries, 21 had isolated head injuries and 19 had isolated vertebral fractures. The remaining patients were 887 patients with an 
abdominal visceral injury and 862 patients that were coded as other external causes of injury.

Of the 887 patients that presented visceral abdominal injuries their main injury was a liver injury in 679 cases, a splenic injury in 166 cases, a small bowel injury in 24 cases, a gastric injury in 4 cases and 3 pancreatic lesions. The remaining 11 cases had a main discharge diagnosis of a colon injury. All the other patients with abdominal visceral injuries were evaluated for concomitant colon injuries but none were found. The 11 cases with a main discharge or death diagnosis of colon injury were the cases we analyzed. Fig. 1 shows a flowchart of the process of patient identification using a PRISMA framework (6).
All 11 patients were male with a mean age of 42 years old. Seven patients were from an urban environment and 4 from a rural environment. Seven patients presented after sustaining blunt trauma (motor vehicle accidents in 6 cases and one fall from a bike) and 4 patients presented after penetrating injuries. Injuries were located in the following parts of the large bowel: 6 at the sigmoid colon, 2 at the cecum, 1 at the transverse colon and one each for ascending and descending colon. The lesions were graded according to the AAST as follows: 1 grade I lesion, 6 grade II lesions, 2 grade III lesions, and 2 grade IV lesions. A colostomy was fashioned in four patients while the rest were repaired with suture. Five patients had no associated intra-

Figure 1. Flowchart of patient identification process

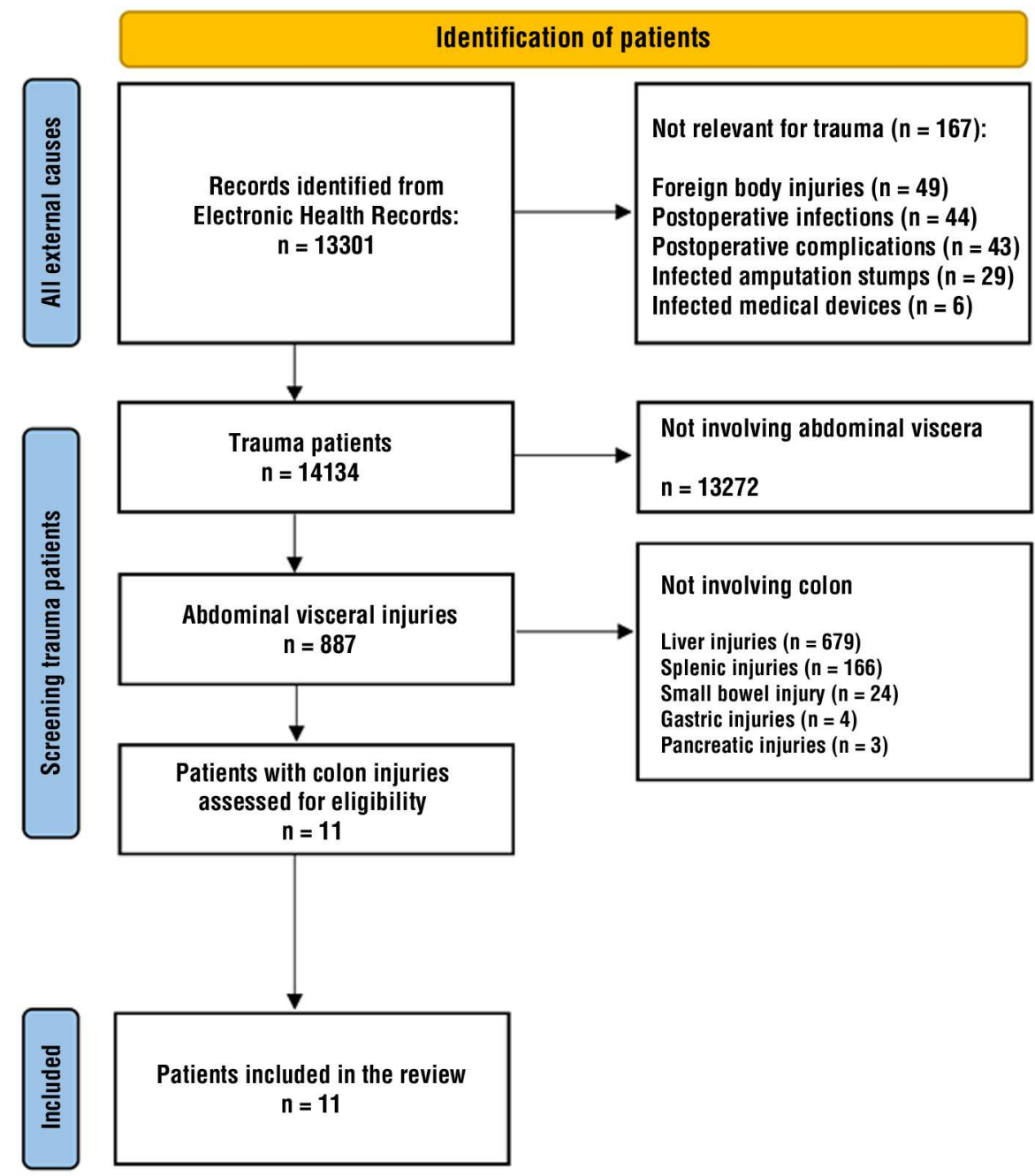


abdominal injuries and 6 had other visceral injuries as follows: 4 cases had small bowel injuries, 1 case had a splenic injury, 1 case had a liver injury, 1 case had a mesenteric injury and one case presented with a zone III retroperitoneal hematoma. Of the 4 cases with small bowel injuries all had a high grade injury that required resection followed by anastomosis - three grade $\mathrm{V}$ and one grade IV lesions (AAST injury scale). Three patients were operated 24 hours or more after the time of injury - one was operated immediately after admission but sustained the trauma more than 48 hours before and two were admitted and operated later. From the last two one had unrecognized lesions and was operated 2 days after admission and the other had a delayed traumatic rupture and was operated immediately after abdominal pain began. Overall, we recorded three deaths one in the patient with the delayed presentation and two in patients that were operated immediately after arrival. Only one patient required multiple interventions and survived to discharge. A detailed view of each case can be found in Table 1.

\section{Discussions}

One of the most striking results of our series is the distribution of injury mechanisms among the 11 patients that had trauma to the large bowel. Small and large bowel injuries are primarily the result of penetrating injuries (7). Colonic injuries may also occur during invasive procedures, like colonoscopies; their severity is decreased due to the mechanical preparation of the colon, before the procedure (8).

Our series showed a penetrating mechanism in only 4 out of 11 patients $(36.3 \%)$ while the majority of patients sustained blunt trauma, almost exclusively motor vehicle accidents. This difference from the existing literature is a powerful example of the etiology of colonic injuries in a civilian environment with rare penetrating trauma. As was expected, most lesions, 7 out of $11(63.6 \%)$, were located in the sigmoid or transverse colon which are more exposed because of their anterior position, compression against the vertebral bodies and mesenteric fixation (9).

In our series mortality was relatively high when compared to modern literature. We recorded 3 deaths from 11 patients, almost $30 \%$. All three deaths were recorded in patients over 50 years old - in two cases the operation was performed immediately after trauma and in the remaining case more than 48 hours after trauma. First two patients died

Table 1. Detailed view of the case series

\begin{tabular}{|c|c|c|c|c|c|c|c|}
\hline No* & Mechanism & Location of injury & AAST grade & Associated injuries & Procedure & Timing** & Outcome \\
\hline $1 / 36$ & Penetrating & Descending colon & $\|$ & None & Suture & $<24 h$ & Discharge \\
\hline $2 / 46$ & Penetrating & Cecum & II & None & Suture & $<24 \mathrm{~h}$ & Discharge \\
\hline $3 / 53$ & Blunt & Sigmoid colon & III & $\begin{array}{c}\text { Spleen } \\
\text { Small bowel }\end{array}$ & $\begin{array}{c}\text { Enterectomy } \\
\text { with anastomosis } \\
\text { Splenectomy }\end{array}$ & $<24 \mathrm{~h}$ & Death \\
\hline $4 / 34$ & Penetrating & Cecum & II & None & Suture & $<24 \mathrm{~h}$ & Discharge \\
\hline $5 / 28$ & Penetrating & Sigmoid colon & II & Small bowel & $\begin{array}{c}\text { Enterectomy } \\
\text { with anastomosis }\end{array}$ & $<24 \mathrm{~h}$ & Discharge \\
\hline $6 / 21$ & Blunt & Transverse colon & II & Liver mesentery & Suture & $<24 \mathrm{~h}$ & Discharge \\
\hline $7 / 65$ & Blunt & Sigmoid colon & IV & Small bowel & $\begin{array}{l}\text { Colostomy } \\
\text { Enterectomy with } \\
\text { anastomosis }\end{array}$ & $>24 \mathrm{~h}$ & Death \\
\hline $8 / 41$ & Blunt & Sigmoid colon & I & None & Suture & $<24 \mathrm{~h}$ & Discharge \\
\hline $9 / 21$ & Blunt & Sigmoid colon & III & Small bowel & Colostomy & $>24 h$ & $\begin{array}{c}\text { Discharge } \\
\text { (after } 3 \text { reoperations) }\end{array}$ \\
\hline $10 / 60$ & Blunt & Sigmoid colon & IV & $\begin{array}{l}\text { Zone III retroperitoneal } \\
\text { hematoma }\end{array}$ & Colostomy & $<24 \mathrm{~h}$ & Death \\
\hline$\overline{11 / 52}$ & Blunt & Ascending colon & $\|$ & None & Suture & $>24 \mathrm{~h}$ & Discharge \\
\hline
\end{tabular}

* - number of the patient in the case series; ${ }^{\star \star}$ - in relation to trauma 
of multiple organ failure due to hemorrhage in the perioperative period and the third from sepsis 3 days after trauma - Trunkey's second and third peaks of mortality (10). We feel that the third death is correctly regarded as in the third peak as hemorrhage cannot explain the outcome and sepsis can occur sooner than the classic second or third week if the injury is not addressed immediately.

All penetrating injuries were operated on as soon as considered necessary (emergency laparotomy for hemorrhage) or as soon as logistically reasonable(stable patients operated in less than 24 hours). Of the three who were operated on later than 24 hours after trauma one was described earlier (the patient who presented more than 48 hours after trauma, patient number 7 in our series), one had injuries that were missed until the patient developed peritonitis and the third is a case of delayed colonic rupture. The patient (number 11) was admitted following a motor vehicle accident for pulmonary contusion and multiple rib fractures for observation and pain control. In the sixth day of admission he developed sudden, acute, abdominal pain and a sensation of abdominal distension. A computed tomography of the abdomen revealed pneumoperitoneum and exploratory laparoscopy revealed a small opening in the ascending colon in the middle of a partial thickness tear of the taenia coli. The opening was repaired with simple sutures and a running suture was used to reapproximate the taenia (Fig. 2). Delayed rupture is rare with few reported cases in the literature (11) and highlights the need to immediately act upon symptoms that might suggest hollow viscus injuries in trauma patients even after a symptom-free interval.

In our series all patients were treated with repair or with colostomies and no anastomoses were performed. This highlights that current literature that shows that primary anastomosis is safe $(3,12)$ and that the degree of fecal contamination does not increase the risk for suture line dehiscence (13) has a hard time being adopted. Safety of anastomosis may also be increased by different types of protective techniques, like ileostomy, colostomy or the use of a transanal tube (14). However, we didn't appreciate that any of these methods should be performed in our series of cases. One explanation might be the low volume of colon injuries for the reasons stated above. Stewart et al showed that risk factors for suture dehiscence are significant medical comorbidities or 6 or more units of blood (15). They also draw the distinction between destructive and nondestructive colon wounds, regarding most grade III and above as destructive injuries.

The study has several limitations. The first is that it is retrospective by nature and causal inferences cannot be made. Another limitation is the small number of cases that were analyzed - this can be explained by three circumstances: the low volume of trauma and especially the low volume of penetrating trauma in our country severely limits the caseload; another explanation is the lack of recording of grade I lesions in patients in which the physiologic stress or the injury inventory are extensive; the third explanation might be a lack of case identification by using

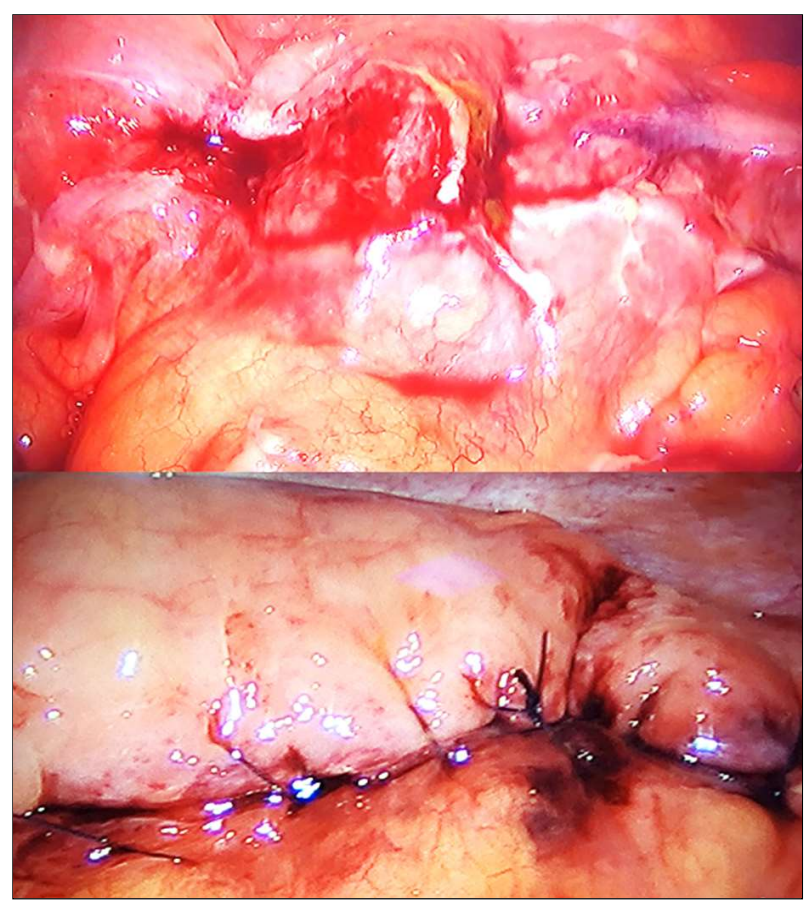

Figure 2. Patient number 11 - delayed ascending colon injury. Above: partial thickness tear of the taenia coli and full thickness opening with bile leaking through. Below: final aspect after repair 
the electronic health records - some injuries might be miscoded or simply not found by the search. Lastly the single center nature of the research limits its scope to the expertise and resources available at our institution. However small our research has value in that it provides several insights in the epidemiology of colon injuries and in the real world management of these injuries outside of carefully controlled studies.

\section{Conclusions}

The main take home message of our research is that the epidemiology of colon trauma is very different in a civilian environment that has a low caseload of penetrating injury compared to wartime injuries. This leads to a slow adoption of modern management options and to a relative lack in exposure to clinical situations - while technical skills can be extrapolated from elective colorectal surgery the management decisions and implementation of specific time-dependent surgery principles may be lacking (no damage control procedures were performed in the cases reviewed although we can safely assume severe physiologic insults in the patients that died in the perioperative period). The differences in the makeup of the colon trauma cohort might also explain high mortality in ours and other predominantly blunt trauma series - a safe assumption is that blunt trauma will lead to a higher degree of physiologic insult through the presence of associated injuries. There is a clear need of prospective multicentre data in this type of trauma cohorts to better define management options and not base our approach on wartime data or data from communities where the rate of penetrating injuries is high.

\section{Conflict of Interest}

The authors declare no conflicts of interests.

\section{Ethical Statement}

All patients provided consent for the trial and the trial is in accordance with the Declaration of Helsinki - Ethical Principles For Medical Research Involving Human Subjects.

\section{References}

1. Steele SR, Maykel JA, Johnson EK. Traumatic injury of the colon and rectum: the evidence vs dogma. Dis Colon Rectum. 2011;54(9):1184-201.

2. Ogilvie WH. Surgical Lessons of War applied to Civil Practice. Br Med J. 1945;1(4400):619-23.

3. Stone HH, Fabian TC. Management of perforating colon trauma: randomization between primary closure and exteriorization. Ann Surg. 1979;190(4): 430-6.

4. Cheong JY, Keshava A. Management of colorectal trauma: a review. ANZ J Surg. 2017;87(7-8):547-53.

5. Injury Scoring Scale [Internet]. The American Association for the Surgery of Trauma. 2009 [cited 2021 Nov 18]. Available from: https://www.aast.org/ resources-detail/injury-scoring-scale

6. Page MJ, McKenzie JE, Bossuyt PM, Boutron I, Hoffmann TC, Mulrow CD, et al. The PRISMA 2020 statement: an updated guideline for reporting systematic reviews. BMJ. 2021;372:n71.

7. Greer LT, Gillern SM, Vertrees AE. Evolving colon injury management: a review. Am Surg. 2013;79(2):119-27.

8. Doran H, Marin IT, laciu M, Patrascu T. latrogenic perforations during colonoscopy. Chirurgia. 2014;109(4):523-6

9. Cleary RK, Pomerantz RA, Lampman RM. Colon and rectal injuries. Dis Colon Rectum. 2006;49(8):1203-22.

10. Trunkey DD. Trauma. Accidental and intentional injuries account for more years of life lost in the U.S. than cancer and heart disease. Among the prescribed remedies are improved preventive efforts, speedier surgery and further research. Sci Am. 1983;249(2):28-35.

11. Ertugrul G, Coskun M, Sevinc M, Ertugrul F, Toydemir T. Delayed presentation of a sigmoid colon injury following blunt abdominal trauma: a case report. J Med Case Reports. 2012;6(1):247.

12. Gonzalez RP, Merlotti GJ, Holevar MR. Colostomy in penetrating colon injury: is it necessary? J Trauma. 1996;41(2):271-5.

13. Miller PR, Fabian TC, Croce MA, Magnotti LJ, Elizabeth Pritchard F, Minard $G$, et al. Improving outcomes following penetrating colon wounds: application of a clinical pathway. Ann Surg. 2002;235(6):775-81.

14. Okuda $Y$, Shimura $T$, Kato $H$, Yamada T, Hirata $Y$, Natsume $M$, et al. Pathological impact of transanal colorectal tube for obstructive colorectal cancer. Surg Endosc. 2020;34(9):4011-4018.

15. Stewart RM, Fabian TC, Croce MA, Pritchard FE, Minard G, Kudsk KA. Is resection with primary anastomosis following destructive colon wounds always safe? Am J Surg. 1994;168(4):316-9. 